\title{
Effect of processing on polyamine content and bioactive peptides released after in vitro gastrointestinal digestion of infant formulas
}

\author{
C. Gómez-Gallego, ${ }^{* 1}$ I. Recio,† V. Gómez-Gómez, ${ }^{*}$ I. Ortuño,‡ M. J. Bernal,‡ G. Ros, ${ }^{*}$ and M. J. Periago* \\ *Department of Food Science and Nutrition, Faculty of Veterinary Sciences, University of Murcia, Campus de Espinardo, 30071, \\ Espinardo (Murcia), Spain \\ †Department of Food Analysis and Bioactivity, Institute of Food Science, Spanish National Research Council (CIAL-CSIC), 28049, Madrid, Spain \\ $\ddagger$ Research and Development Department, Hero Spain S.A., 30820, Alcantarilla, Spain
}

\section{ABSTRACT}

This study examined the influence of processing on polyamines and peptide release after the digestion of a commercial infant formula designed for children during the first months of life. Polyamine oxidase activity was not suppressed during the manufacturing process, which implicates that polyamine concentrations were reduced over time and during infant formula self-life. In gel electrophoresis, in vitro gastrointestinal digestion of samples with reduced amount of enzymes and time of digestion shows an increase in protein digestibility, reflected in the increase in nonprotein nitrogen after digestion and the disappearance of $\beta$-lactoglobulin and $\alpha$-lactalbumin bands in gel electrophoresis. Depending on the sample, between 22 and 87 peptides were identified after gastrointestinal digestion. A peptide from $\beta$-casein $\mathrm{f}(98-105)$ with the sequence VKEAMAPK and antioxidant activity appeared in all of the samples. Other peptides with antioxidant, immunomodulatory, and antimicrobial activities were frequently found, which could have an effect on infant health. The present study confirms that the infant formula manufacturing process determines the polyamine content and peptidic profile after digestion of the infant formula. Because compositional dissimilarity between human milk and infant formula in polyamines and proteins could be responsible for some of the differences in health reported between breast-fed and formula-fed children, these changes must be taken into consideration because they may have a great effect on infant nutrition and development.

Key words: infant formula, polyamine, peptide, simulated gastrointestinal digestion, mass spectrometry

Received June 30, 2015.

Accepted October 14, 2015.

${ }^{1}$ Corresponding author: carlosgg@um.es

\section{INTRODUCTION}

Breast milk has a complex composition of nutrients and bioactive components designed to fulfill the needs of the growing infant. In recent years, the infant food industry has made an effort to develop infant formulas that are more similar to human milk to improve the nutrition of infants who are not breastfeeding.

Protective compounds, such as cytokines, oligosaccharides, and even microbes, in breast milk provide the newborn with the means to adapt to the environment (Gueimonde et al., 2007; Newburg and Walker, 2007). Among the bioactive compounds found in breast milk are polyamines, such as, spermidine, spermine, and putrescine, as well as bioactive peptides released during milk protein digestion. Polyamines have a positive effect on the development of the gastrointestinal tract (Larqué et al., 2007) and immune system (Pérez-Cano et al., 2010; Gómez-Gallego et al., 2014b). The levels and effects of these compounds in infant formulas compared with human milk are of special interest, because their concentrations are lower than in human milk (Buts et al., 1995). Moreover, dietary proteins are a source of biologically active peptides that are inactive within the sequence of parent protein and can be released during gastrointestinal digestion or food processing. Once bioactive peptides are liberated, they may act as regulatory compounds. Bioactive peptides are widely distributed among milk protein sequences (Clare and Swaisgood, 2000), which can be released during digestion in vivo. However, changes that take place in protein structure during the manufacturing of infant formulas can influence protein digestion and peptide liberation (Korhonen et al., 1998).

Technological processes used in food manufacturing affect the functional, nutritional, and biological properties of food components. Depending on the intensity of the heat treatment, the nutritive value of proteins can be affected in a positive or negative way (Korhonen et al., 1998) and, by extension, can affect other related compounds.

The structure of milk is greatly altered depending on the various mechanical and thermal steps of the 
processing chain (Michalski and Januel, 2006). Heating and homogenization are the most common and most widely used methods capable of modifying proteins during infant formula manufacturing. Among the different physical and chemical changes, a great deal of attention has been focused on the covalent interaction of protein-carbohydrate via the Maillard reaction. During this reaction, the conjugation of a reducing carbohydrate to the 3-amino group of lysine occurs spontaneously under heating conditions (Corzo-Martínez et al., 2012). Some studies have shown contradicting effects regarding the Maillard reaction. On one hand, glycation can lead structural changes, which could generate new enzymatic cleavage sites (Corzo-Martínez et al., 2012; Joubran et al., 2015) modulating protein digestibility and peptides release after digestion. On the other hand, conjugation could limit enzymatic accessibility through steric hindrance (Joubran et al., 2015). These 2 counteracting effects could explain the different digestive patterns reported for other authors. Moreover, heat treatment changes the effect of homogenization on milk structure (Michalski and Januel, 2006). The main effect of homogenization on soluble milk components is the disruption of casein micelles in micellar form or as fragments. Homogenization seems to improve milk digestibility. However, heat treatment changes the effect of homogenization on milk structure, and it has been reported that infants better digest native human milk fat globules than homogenized droplets from infant formula (Michalski and Januel, 2006). As concluded by Michalski and Januel (2006), the structural consequences in milk proteins seem to depend on the sequence of the homogenization and heat treatments, but they are rather controversial because of the various treatments applied and to the different procedures used in the food industry.

The aims of this study were to evaluate how formula processing influences polyamine content and peptide release after digestion. Furthermore, the behavior of the polyamine oxidase activity of the milk and the digestibility of proteins were studied. The results of this work could be a preliminary step to improving infant formula composition, which could promote better health status of children fed with infant formulas during the first months of life.

\section{MATERIALS AND METHODS}

\section{Samples}

The infant formula samples used in this study were supplied by Hero España S.A. (Alcantarilla, Spain) at different representative stages along the manufacturing process. Figure 1 shows the flow diagram of the infant

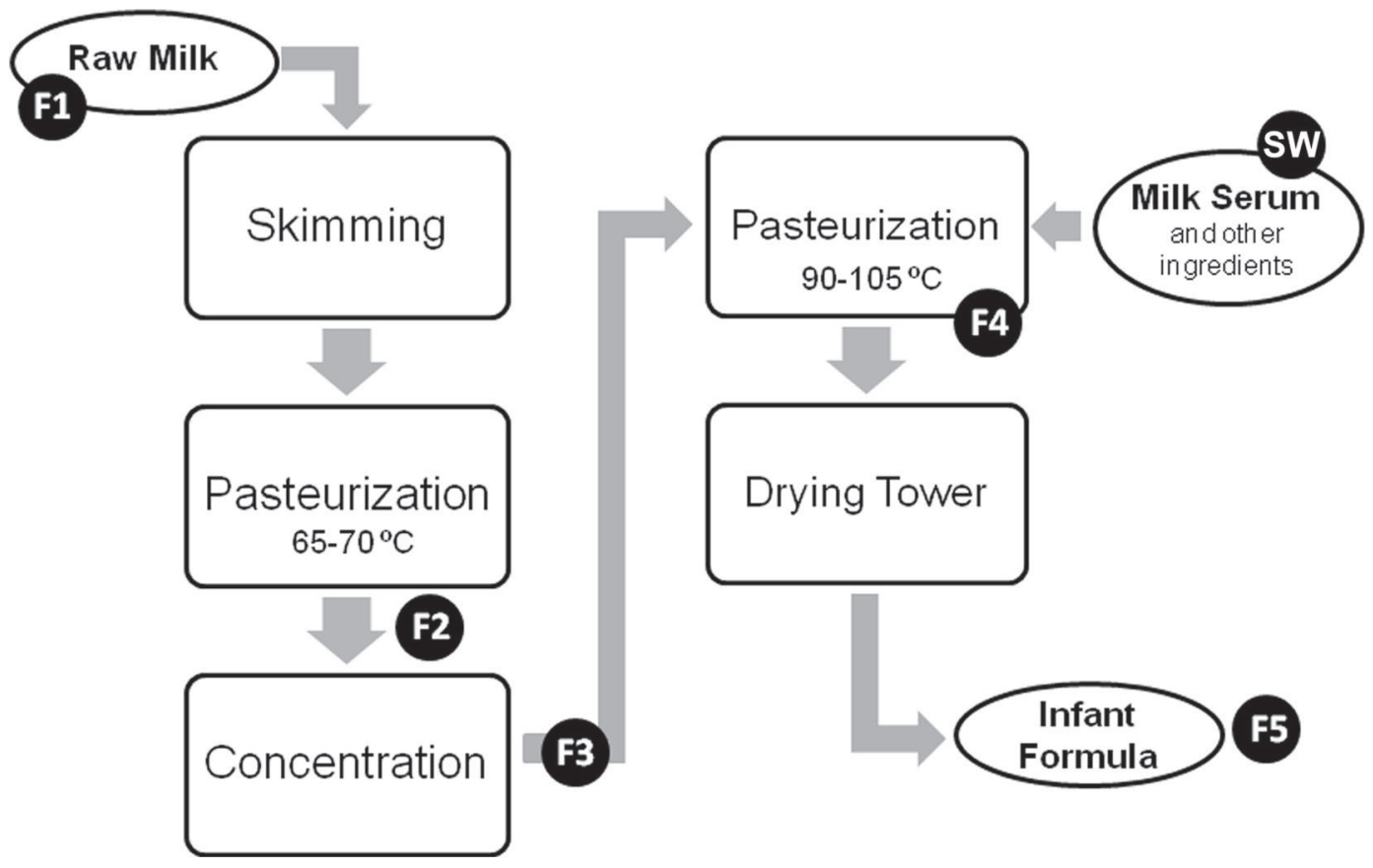

Figure 1. Diagram of infant formula manufacturing process. Samples were taken in the steps labelled with a black circle, from originally raw milk (F1) to final infant formula ready for sale (F5). In the first concentration stage, the product was concentrated by 30 to $40 \%$. The process included a two-step homogenization. In the fluidized bed spray-dryer tower the water was removed to a final moisture of $3 \%$. F1 $=$ cow milk; F2 = cow milk after skimming and the first thermal treatment; F3 = concentrated milk after the second thermal treatment; F4 = concentrated infant formula after the last thermal treatment; F5 = the infant formula final product; and $\mathrm{SW}=$ milk whey used as an ingredient. 
formula manufacturing process and the steps at which the samples were taken. The samples were $(\mathbf{F 1})$ cow milk used as raw material in infant formula processing; (F2) cow milk after skimming and the first thermal treatment; (F3) concentrated milk after the second thermal treatment; (F4) concentrated infant formula after the last thermal treatment; (F5) the infant formula final product; and (SW) milk whey used as an ingredient. Whey was demineralized sweet whey from cow milk, with a content of lactose around $70 \%$, added as an ingredient to increase milk serum proteins in the final product to $60 \%$ of total proteins.

One kilogram of powdered infant formula (F5) and 500-mL aliquots of liquid samples (F1, F2, F3, F4, and SW) were taken from 5 different batches separately. Liquid samples were lyophilized, and all of the samples were preserved at $-20^{\circ} \mathrm{C}$ until analysis.

\section{Determination of Moisture and Nitrogen}

Moisture (method 964.22) along the infant formula manufacturing process and nitrogen $(\mathrm{N})$ content using the micro-Kjeldahl procedure (method 955.04) were determined in the samples and digestions using official AOAC methods (AOAC, 1990). Protein calculations were made using 6.25 as the conversion factor. Nonprotein nitrogen in the samples and digestions was estimated using the micro-Kjeldahl method after dissolving $20 \mathrm{~g}$ of the sample in $100 \mathrm{~mL}$ of $15 \%$ TCA for milk protein precipitation and filtration.

\section{Analysis of Polyamines}

An HPLC method using a diode array detector was used. The HPLC system consisted of a Waters 2690 system connected to a Waters 910 detector. The analytical column was a Spherisorb 5.0- $\mu \mathrm{m}$ ODS2, $4.6 \mathrm{~mm}$ $\times 150 \mathrm{~mm}$ (Waters Corp., Milford, MA). Detection was performed at $254 \mathrm{~nm}$.

The samples were diluted 10 times with a solution of TCA as described by Nishibori et al. (2007), but the concentration was adjusted to $15 \%$ for milk protein precipitation. The samples were homogenized using gentle agitation for 30 min (Pollack et al., 1992). After centrifugation at $13,000 \times g$ for $15 \mathrm{~min}$ at $4^{\circ} \mathrm{C}$, the supernatants were filtered using $0.45-\mu \mathrm{m}$ membrane filters (Whatman, Brentford, UK) and dansylated by adapting the method described by Buts et al. (1995). Clear supernatant $(1 \mathrm{~mL})$ was basified by adding 250 $\mu \mathrm{L}$ of saturated sodium carbonate and $1 \mathrm{~mL}$ of dansyl chloride solution $(10 \mathrm{mg} / \mathrm{mL}$ of acetone; Fluka, Steinheim, Germany).

After incubation, $200 \mu \mathrm{L}$ of L-proline solution (Scharlau, Barcelona, Spain) was added to clean the excess
Table 1. Gradient of acetonitrile:water used to separate dansylated polyamines

\begin{tabular}{lcc}
\hline Time $(\min )$ & Acetonitrile $(\%)$ & Water $(\%)$ \\
\hline 0 & 60 & 40 \\
5 & 60 & 40 \\
15 & 70 & 30 \\
20 & 95 & 5 \\
25 & 98 & 2 \\
26 & 98 & 2 \\
26.1 & 61 & 39 \\
30 & 60 & 40 \\
\hline
\end{tabular}

dansyl chloride (Escribano, 1990). Extraction of dansyl derivatives was performed twice with cyclohexane, and organic phases were collected and evaporated in nitrogen air flow. Residues of dansyl derivatives were dissolved in $1 \mathrm{~mL}$ of acetonitrile (Merck, Darmstadt, Germany) and filtered with $0.45-\mu \mathrm{m}$ HPLC filters (Upchurch Scientific, Oak Harbor, WA). Aliquots of $20 \mu \mathrm{L}$ were injected in the HPLC. Samples were run for 30 min according to a linear gradient method including 2 mobile phases: water and acetonitrile (Table 1).

Each sample was analyzed in duplicate. Quantification of the polyamine concentration was made by comparing the integrated surface areas of peaks with areas of dansylated polyamines of known concentration on a standard curve. To avoid mistakes due to loss of dansylated polyamines during manipulation, 1,3-diaminopropane (Aldrich, Steinheim, Germany) was used as the internal standard (Tovar, 2002). Polyamine concentrations were expressed in milligrams per kilogram.

\section{Analysis of Polyamine Oxidase Activity}

The polyamine oxidase (PAO) activity assay was performed using the method described by Suzuki et al. (1984) in which hydrogen peroxide formed by polyamine oxidase is measured fluorometrically by converting homovanillic acid to a highly fluorescent compound by peroxidase, adding pargyline and semicarbazide for monoamine oxidase and diamine oxidase inhibition, respectively. A multimode microplate reader (Synergy 2; Bio-Tek, Winooski, VT); fluorescence filters with excitation and emission wavelengths of 360 and $460 \mathrm{~nm}$, respectively; and 96-well black, flat-bottomed microplates were used to carry out this assay. Each sample was analyzed in triplicate. Results were expressed as micromoles of $\mathrm{H}_{2} \mathrm{O}_{2}$ per milligram of dry extract per $30 \mathrm{~min}$.

\section{In Vitro Gastrointestinal Digestion of Samples}

The hydrolysis procedure was based on the method described by Miller et al. (1981) and comprised the simulation of gastric and intestinal digestion of the samples 
by in vitro enzymatic treatment. The modifications introduced by different authors (Bosscher et al., 2001; Jovani et al., 2001; Hernández-Ledesma et al., 2007; Frontela et al., 2008; Bourlieu et al., 2014) reduced the concentrations of digestive enzymes and the time of digestion, to simulate gastrointestinal conditions during lactation. In the first step, $3.9 \mathrm{~g}$ of the dry extract of the sample was dissolved in $10 \mathrm{~mL}$ of Milli-Q water obtained using a Milli-Q water purification system (Millipore, Molsheim, France). Then, the $\mathrm{pH}$ was adjusted to 4.0 with $1 \mathrm{M} \mathrm{HCl}$, and the samples were hydrolyzed with pepsin (from porcine gastric mucosa; Sigma, St. Louis, MO) at a ratio of $10.7 \mathrm{mg}$ of pepsin per gram of sample, for $30 \mathrm{~min}$ at $37^{\circ} \mathrm{C}$. Directly afterward, the $\mathrm{pH}$ of the digested sample was raised to 5.0 using sodium hydrogen carbonate $1 \mathrm{M}$, and the samples were hydrolyzed with pancreatin (from porcine pancreas; Sigma) and bile salts (Fluka), at a ratio of $2 \mathrm{mg}$ of pancreatin per gram of the sample and $6.25 \mathrm{~g}$ of bile salts per gram of pancreatin. Intestinal digestion with pancreatin was performed at $37^{\circ} \mathrm{C}$ for 90 min. Digestion was carried out in a thermally controlled incubator under constant stirring. The reaction was stopped, the sample was put on ice, and the $\mathrm{pH}$ was adjusted to 7.2 with sodium hydrogen carbonate $1 M$. The enzymes were inactivated by heating at $95^{\circ} \mathrm{C}$ for $15 \mathrm{~min}$ in a water bath, followed by cooling to room temperature. A fraction of the digestions were run in gel electrophoresis to check for the presence of proteins and changes in protein composition. Digestibility and reverse-phase-HPLCtandem mass spectrometry analyses were performed to evaluate influence of the processing in peptide release after digestion. In vitro gastric and intestinal digestions and subsequent analyses were carried out at least in duplicate.

Protein digestibility was calculated as the increase in NPN following gastrointestinal digestion, as described by Rudloff and Lönnerdal (1992). Nitrogen content of fractions was determined as described previously, employing the Kjeldahl procedure.

\section{Gel Electrophoresis}

To investigate the protein composition of milk fractions during digestion, the molecular weights of the proteins were analyzed by gel electrophoresis in SDS. The analysis was conducted using a PhastSystem electrophoresis system (Pharmacia, Uppsala, Sweden) as described by Jiménez-Saiz et al. (2011), with precast homogenous gels 20\% (GE Healthcare, New York, NY) and PhastGel SDS buffer strips (Amersham Biosciences Corp., Uppsala, Sweden), following the manufacturer's instructions for the electrophoretic and Coomassie staining conditions. The samples were dissolved in 10- $\mathrm{m} M$ Tris- $\mathrm{HCl}$ buffer, $\mathrm{pH}$ 8.0, containing 2.5\% SDS and $10 \mathrm{~m} M$ EDTA, and heated at $95^{\circ} \mathrm{C}$. They were then analyzed in the presence of $5 \% 2-\beta$-mercaptoethanol.

\section{Analysis by Online Reverse-Phase-HPLC-Tandem Mass Spectroscopy}

A water-soluble hydrolysate extract was obtained by centrifugation at $20,000 \times g$ for $30 \mathrm{~min}$ at $5^{\circ} \mathrm{C}$ and by filtration through a Whatman no. 41 filter (GE Healthcare Bio-Sciences, Pittsburgh, PA). The watersoluble extract was subjected to ultrafiltration through a hydrophilic 1,000-Da cutoff membrane (Amicon Inc., Beverly, MA).

The hydrolysates were injected into an HPLC system (Agilent, Santa Clara, CA), which was connected online to an Esquire-LC quadrupole ion trap instrument (Bruker Daltonik, Bremen, Germany), according to the method of Hernández-Ledesma et al. (2004). The column used in these experiments was a $250-\mathrm{mm} \times 4.6-$ mm Discovery BIO Wide Pore C18 column (Bio-Rad, Richmond, CA). A Nova-Pak C18 guard column 20 $\mathrm{mm} \times 3.9 \times 4 \mu \mathrm{m}$ (Waters Corp.) was used to protect the analytical column. The injection volume was $50 \mu \mathrm{L}$. Solvent A was a mixture of water and trifluoroacetic acid (1,000:0.37, vol/vol), and solvent B contained acetonitrile and trifluoroacetic acid (1,000:0.27, vol/vol). Peptides were eluted with a linear gradient of 0 to $45 \%$ solvent B over $60 \mathrm{~min}$ at a flow rate of $0.8 \mathrm{~mL} / \mathrm{min}$. The signal threshold to perform auto mass spectrometry(n) analyses was 1,000, and the precursor ions were isolated within a range of $4.0 \mathrm{~m} / z$ and fragmented with a voltage ramp going from 0.35 to $1.4 \mathrm{~V}$. The $\mathrm{m} / z$ spectral data were processed using Data Analysis 3.0 (Bruker Daltonik) and transformed to spectra representing mass values. Mass spectrometry(n) spectra were processed in BioTools 2.1 (Bruker Daltonik) to perform peptide sequencing.

\section{Statistical Analysis}

Statistical analyses were conducted using ANOVA and relevant post hoc tests with SPSS 15.0 software (IBM Corp., Armonk, NY). Differences between means were considered significant at $P \leq 0.05$.

\section{RESULTS AND DISCUSSION}

\section{Effect of Processing on Polyamine Content and Polyamine Oxidase Activity of Infant Formulas}

The concentrations of the polyamines detected in the analyzed samples varied over a wide range, probably reflecting differences in the stages of the process from 
Table 2. Polyamine concentration $(\mathrm{mg} / \mathrm{kg}$ ) and range in dry samples along manufacturing process (mean with range in parentheses)

\begin{tabular}{llll}
\hline Sample $^{1}$ & \multicolumn{1}{c}{ Putrescine } & \multicolumn{1}{c}{ Spermidine } & \multicolumn{1}{c}{ Spermine } \\
\hline F1 & $0.650^{\mathrm{a}}(0.576-0.749)$ & $0.057^{\mathrm{a}}(0-0.124)$ & $0.065^{\mathrm{a}}(0-0.140)$ \\
F2 & $1.047^{\mathrm{ab}}(0.680-1.380)$ & $0.126^{\mathrm{a}}(0.116-0.151)$ & $0.125^{\mathrm{ab}}(0.124-0.129)$ \\
F3 & $1.858^{\mathrm{abc}}(0.170-3.950)$ & $0.967^{\mathrm{bc}}(0.038-1.779)$ & $0.469^{\mathrm{abc}}(0-1.084)$ \\
F4 & $2.824^{\mathrm{c}}(1.369-7.757)$ & $1.118^{\mathrm{c}}(0.661-2.009)$ & $0.756^{\mathrm{bc}}(0.376-1.367)$ \\
F5 & $2.441^{\mathrm{bc}}(1.339-3.492)$ & $0.576^{\mathrm{ab}}(0.271-0.983)$ & $0.466^{\mathrm{abc}}(0.137-1.210)$ \\
SW & $3.109^{\mathrm{c}}(1.670-5.610)$ & $0.406^{\mathrm{a}}(0-0.761)$ & $0.948^{\mathrm{c}}(0-1.935)$ \\
\hline
\end{tabular}

${ }^{a-c}$ Different letters in the same column indicate statistical significant differences at the level of $P<0.001$.

${ }^{1} \mathrm{~F} 1=$ cow milk; F2 = cow milk after skimming and the first thermal treatment; F3 = concentrated milk after the second thermal treatment; F4 = concentrated infant formula after the last thermal treatment; F5 $=$ the infant formula final product; and SW = milk whey used as an ingredient.

where the samples were taken, the original raw milk of the batch, and the PAO activity of the sample. The results are summarized in Table 2. Overall, polyamine content was lower in the first steps of the processing than in the last steps or final product. This could be due to the PAO activity in these samples (Table 3 ) influenced for whey addition before the last concentration stage. With respect to PAO activity of the raw milk, the final infant formula retained more than $60 \%$ of the enzymatic activity, which was not inactivated because of the high resistance of the enzyme. This persistent PAO activity changes polyamine concentrations over time and during infant formula reconstitution.

As reported in previous studies (Pollack et al., 1992; Romain et al., 1992; Buts et al., 1995), the polyamine content in infant formula is around 10 times less than that of human milk. In our samples, if the formula was reconstituted according to the manufacturer's instructions, the final concentrations of putrescine, spermidine, and spermine would be $0.317,0.075$, and $0.061 \mathrm{mg} /$ $\mathrm{kg}$, respectively. These amounts were similar to those reported by Romain et al. (1992), with higher levels

Table 3. Polyamine oxidase (PAO) activity ( $\mu \mathrm{mol}$ of $\mathrm{H}_{2} \mathrm{O}_{2} / \mathrm{mg}$ of dry extract per $30 \mathrm{~min}$ ) in samples along manufacturing process and evolution of the percentage of relative PAO activity comparing with raw milk

\begin{tabular}{llc}
\hline Sample $^{1}$ & $\begin{array}{c}\text { PAO activity } \\
(\text { mean } \pm \text { SD })\end{array}$ & $\begin{array}{c}\text { Relative PAO } \\
\text { activity (\%) }\end{array}$ \\
\hline F1 & $21.59^{\mathrm{a}} \pm 2.31$ & 100.00 \\
F2 & $25.27^{\mathrm{a}} \pm 0.72$ & 117.04 \\
F3 & $11.94^{\mathrm{b}} \pm 1.43$ & 55.30 \\
F4 & $11.98^{\mathrm{b}} \pm 3.58$ & 55.49 \\
F5 & $14.48^{\mathrm{b}} \pm 0.45$ & 69.38 \\
SW & $15.44^{\mathrm{b}} \pm 3.23$ & 71.51 \\
\hline
\end{tabular}

${ }^{\mathrm{a}, \mathrm{b}}$ Different letters in the same column indicate statistical significant differences at the level of $P<0.001$.

${ }^{1} \mathrm{~F} 1=\mathrm{cow}$ milk; $\mathrm{F} 2=\mathrm{cow}$ milk after skimming and the first thermal treatment; F3 = concentrated milk after the second thermal treatment; F4 = concentrated infant formula after the last thermal treatment; F5 = the infant formula final product; and SW = milk whey used as an ingredient. for putrescine. Previous studies (Pollack et al., 1992; Romain et al., 1992; Buts et al., 1995; Dorhout et al., 1996) established a great variation in milk composition from one mother to another and even between the left and right breasts (Buts et al., 1995), but the average concentrations of polyamines were around 0.058, 0.580 , and $0.825 \mathrm{mg} / \mathrm{kg}$ for putrescine, spermidine, and spermine, respectively. Thus, the concentrations of spermidine and spermine, the most active polyamines (Larqué et al., 2007) in manufactured formulas, were much lower than in human milk, although the concentration of putrescine was higher than in breast milk. This finding reveals the lack of an important functional compound in infant formulas compared with breast milk, and because of the role of polyamines on immunesystem and intestinal-microbiota development, we recently reported (Gómez-Gallego et al., 2014a,b) that the development of infant formulas with a high but safe polyamine content must be taken into consideration.

\section{Effect of Processing on Digestibility of Milk Proteins in Infant Formulas}

The protein composition of fractions was further characterized by gel electrophoresis. We found that the processing of infant formulas had an influence on the protein structure. The comparison between raw milk (F1) and infant formula (F5) shows that processing alters bands on SDS gels (Figure 2; lanes 1 and 2, versus 5 and 6 ). As reported by other authors (Barbé et al., 2013), heat treatment induced susceptibility to hydrolysis, thereby facilitating protein digestion, which was reflected in band comparison after gastric and gastrointestinal digestion (Figure 2; lanes 3 and 4, versus 7 and 8$)$. It is mainly evident in the $\beta$-LG and $\alpha-\mathrm{LA}$ bands, which persist in raw milk after gastrointestinal digestion and practically disappear during digestion in infant formula samples. In raw milk, $\beta$-LG and $\alpha$-LA remain undegraded because of the partial resistance to pepsin and pancreatin in the soft acidic conditions of 
infant in vitro digestion (Korhonen et al., 1998). In the whey samples, proteins seemed to have relatively high resistance to the conditions of digestion, which was reflected in the persistence of the bands for $\beta-\mathrm{LG}$ and $\alpha-\mathrm{LA}$, even after in vitro digestion (Figure 2; lane 12). These results are in accord with data published with other authors, demonstrating that milk proteins persisted longer under infant digestion conditions (Joubran et al., 2015), potentially generating bioactive peptides.

Digestibility was related to the increase in NPN that resulted from enzymatic digestion, as shown in Table 4. Protein digestibility, related to the increase in NPN, was lower in whey (SW), which supported the results confirmed by gel electrophoresis. It appeared that the manufacturing process exerted whey protein denaturation, which facilitated its digestion. At the end of the F5 sample digestion, estimated in vitro digestibility of the F5 sample increased from $17.9 \%$ of the F1 sample to $44.9 \%$. As reported by Rudloff and Lönnerdal (1992), this low digestibility could be due to the soft gastrointestinal digestion conditions during the first months of life as well as lipid-protein or peptide interactions. But, our results were even lower than those reported by other authors.
It is important to consider that in vitro digestibility is only an approximation of the physiological process and does not take into account other characteristics of real digestion, such as gastric emptying, intestinal fluid, intestinal motility, and mucosal enzymes. However, it could be considered a warning regarding real protein digestion during lactation (Binaghi et al., 2002).

\section{Identified Peptides After Gastrointestinal Digestion}

The ultrafiltration permeates of the digested samples were obtained and subjected to tandem mass spectrometry for peptide identification. A total of 49 protein fragments could be identified for raw milk (F1; Supplemental Table S1), 29 for skim milk (F2; Supplemental Table S2), 22 for concentrated milk (F3; Supplemental Table S3), 23 for milk serum (SW; Supplemental Table S4), 55 for concentrated manufactured formula (F4; Supplemental Table S5), and 87 for infant formula (F5; Supplemental Table S6). All supplemental files are at http://dx.doi.org/10.3168/jds.2015-10030.

Evidence is growing that the peptide sequences released during digestion can vary depending on the manufacturing process of infant formulas. As suggested by other authors (Chang et al., 1981), digestion experi-
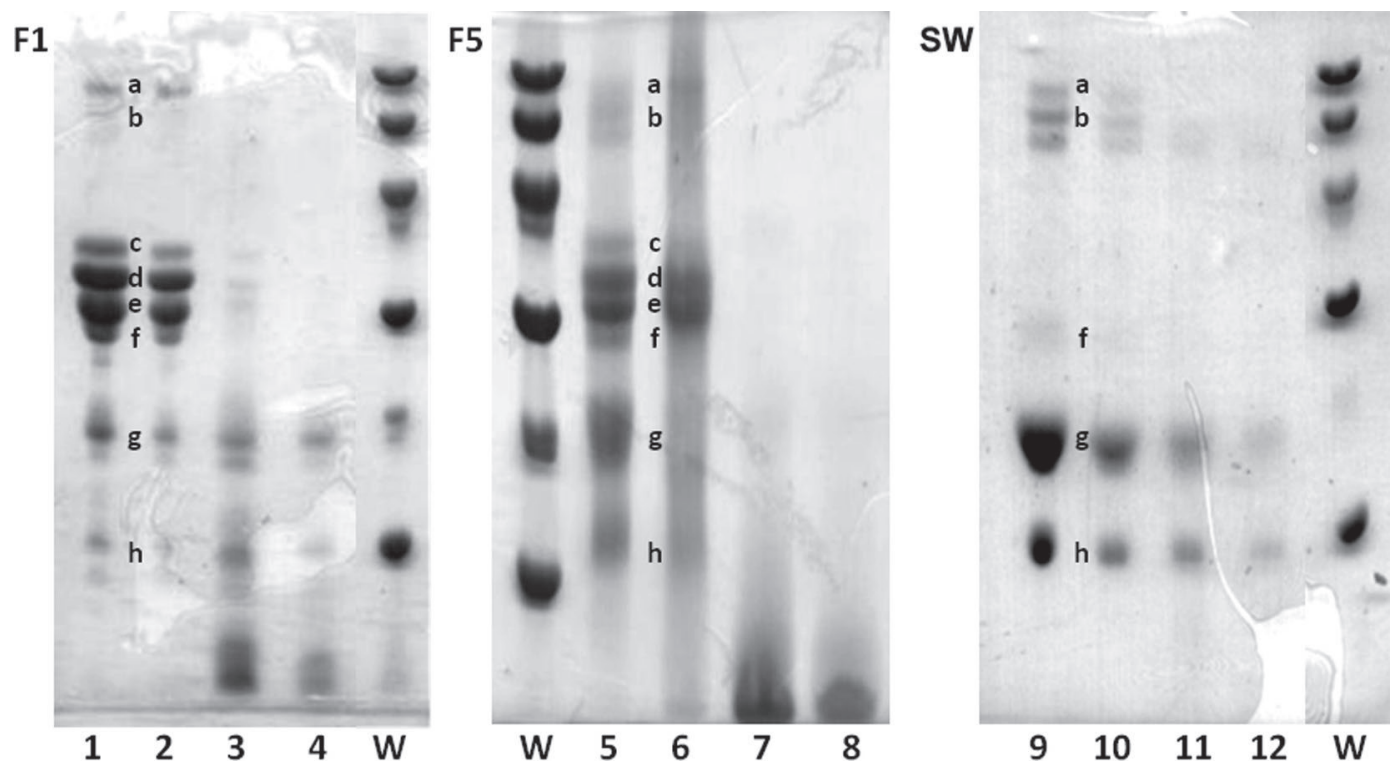

Figure 2. Sodium dodecyl sulfate-PAGE of raw milk (F1); infant formula (F5); and whey (SW) proteins and their fractions along gastrointestinal digestion: lane $1=$ raw milk; lane $2=$ raw milk at infant gastric $\mathrm{pH}(\mathrm{pH}=4)$; lane $3=$ raw milk after infant gastric digestion; lane $4=$ water-soluble extract of raw milk after infant gastrointestinal digestion $($ at $\mathrm{pH}=7$ ); lane $\mathrm{W}=$ molecular weight marker $(97 \mathrm{kDa}=$ phosphorylase b from rabbit muscle; $60 \mathrm{kDa}=\mathrm{BSA} ; 45 \mathrm{kDa}$, ovalbumin; $30 \mathrm{kDa}=$ carbonic anhydrase from bovine erythrocytes; $20.1 \mathrm{kDa}=$ soybean trypsin inhibitor; $14.4 \mathrm{kDa}=$ bovine alpha lactalbumin); lane $5=$ infant formula reconstituted per manufacturer's indications; lane $6=$ infant formula at infant gastric $\mathrm{pH}(\mathrm{pH}=4)$; lane $7=$ infant formula after infant gastric digestion; lane $8=$ water-soluble extract of infant formula after infant gastrointestinal digestion (at $\mathrm{pH}=7)$; lane $9=$ milk serum; lane $10=$ serum at infant gastric $\mathrm{pH}(\mathrm{pH}=4)$; lane $11=$ serum after infant gastric digestion; lane $12=$ water-soluble extract of milk serum after infant gastrointestinal digestion $($ at $\mathrm{pH}=7)$. The positions of lactoferrin $(\mathrm{a})$, serum albumin (b), $\alpha_{\mathrm{s} 2}-\mathrm{CN}(\mathrm{c}), \alpha_{\mathrm{s} 1}-\mathrm{CN}(\mathrm{d}), \beta-\mathrm{CN}(\mathrm{e}), \kappa-\mathrm{CN}(\mathrm{f}), \beta-\mathrm{LG}(\mathrm{g})$, and $\alpha-\mathrm{LA}(\mathrm{h})$ are indicated. 
ments with infant formulas may provide information regarding the susceptibility of proteins to gastrointestinal conditions, hydrolysis, and bioactive peptide release in infant formulas.

The comparison of the majority of peptide profiles in the 1,000-Da permeates showed that changes in the profile of peptides released and identified was greatly dependent on the processing stage of the infant formula. Our results showed that the percentage increases of peptides originating from whey proteins during processing - from $33.3 \%$ in raw milk (F1) to $49.9 \%$ in final infant formula (F5) - may have been due to the addition of whey (SW) as an ingredient.

With the exception of the whey samples (SW), a peptide from $\beta-\mathrm{CN}$ f(98-105) with the sequence VKEAMAPK and antioxidant activity (Korhonen and Pihlanto-Leppäla, 2007) appeared in all of the samples. Other abundant peptides in the samples were ETYG, ELLK, STAV, LPDT, AVVKK, ATAST, IIAEK, EAMAPK, RELEE, RYLG, LRLK, LRLKK, LKKI, VQVTSTAV, YLGY, YSLA, YLGYL, VEGPKLV, and HAQ. Among these peptides, the $\alpha_{\mathrm{s} 1} \mathrm{CN}$ fragment $\mathrm{f}(91-94)$, with the sequence YLGY, had a structure potentially able to act as an opioid receptor ligand. This peptide is a fragment of $\alpha$-casomorphin (Clare and Swaisgood, 2000), which maintains an amino-terminal tyrosine for essential opioid activity (Chang et al., 1981) and an aromatic AA in the third or fourth position that favors peptide union to opioid receptor (Kohmura et al., 1990). Further studies are necessary to confirm the potential opioid activity of this fragment, because it may have an important role in sleeping pattern and the development and function of the gastrointestinal tract in infants depending on its opioid agonistic or antagonistic activity (Wada and Lönnerdal, 2014).

Additionally, some of the peptide sequences found in F1, F2, and F5 samples have been found to exert angiotensin I-converting enzyme (ACE)-inhibitory activities. Their sequences were also described in human milk proteins, and it can be expected that breast-fed infants as well as infants fed with milk-based formulas will obtain ACE-inhibitory peptides, which may play a role in cardiovascular health. It has been proposed than the immaturity-related higher serum ACE activity in early life could program cardiovascular disease later in life but that ACE-inhibitory peptides present in milk might improve this negative effect (Wada and Lönnerdal, 2014). So their presence in formulas and their activity compared with breast milk should be an object of further studies.

Moreover, in the profile of peptides released after gastrointestinal digestion of the final manufactured formula (Supplemental Table S6; http://dx.doi. org/10.3168/jds.2015-10030), peptides with antioxidant (HIQKEDVPSER, VKEAMAPK; Korhonen and Pihlanto-Leppäla, 2007; Gupta et al., 2010), antimicrobial activity (IPAVFK; Pellegrini et al., 2001), ACEinhibitory peptides (FRQF, PLW, RPK, RVY, IIAEK; Maruyama et al., 1987; Matsufuji et al., 1994; Nagaoka et al., 2001; Shahidi and Zhong, 2008; Contreras et al., 2009), a peptide modulator of nonclassical cadherins functions (QUINNK; Blaschuk et al., 1999), and a cathepsin B inhibitor (PFPGPI; Lee and Lee, 2000) were found. It is important to highlight that our results shows some fragments originating from $\beta$-LG, a protein absent in human milk. Two of these peptides - RVY and IPAVFK - were reported to exert ACE-inhibitory and antibacterial activity, respectively. Additional studies are necessary to determine whether these peptides have similar functional properties to human milk, defined for a different peptide profile (Wada and Lönnerdal, 2014). In addition, the fragments of many previously characterized bioactive peptides were found after infant formula (F5) gastrointestinal digestion. Some of these

Table 4. Digestibility of proteins in samples along infant formula manufacturing process

\begin{tabular}{|c|c|c|c|c|c|}
\hline Sample $^{1}$ & $\begin{array}{l}\text { Moisture } \\
(\%)\end{array}$ & $\begin{array}{l}\text { Protein in dry } \\
\text { extract }(\mathrm{mg} / \mathrm{g})\end{array}$ & $\begin{array}{c}\text { NPN before } \\
\text { digestion in dry }_{\text {extract }^{2}(\mathrm{mg} / \mathrm{g})}\end{array}$ & $\begin{array}{c}\text { NPN after } \\
\text { digestion in dry }_{\text {extract }^{2}(\mathrm{mg} / \mathrm{g})}\end{array}$ & $\begin{array}{c}\text { Digestibility }^{2} \\
(\%)\end{array}$ \\
\hline F1 & 88.17 & 26.84 & $0.50 \pm 0.21$ & $1.27 \pm 0.21$ & $17.89 \pm 5.2^{\mathrm{b}}$ \\
\hline F3 & 60.38 & 10.89 & $0.18 \pm 0.12$ & $0.97 \pm 0.20$ & $45.64 \pm 11.80^{\mathrm{a}}$ \\
\hline F4 & 61.11 & 11.23 & $0.24 \pm 0.03$ & $1.03 \pm 0.21$ & $44.99 \pm 11.57^{\mathrm{a}}$ \\
\hline F5 & 1.69 & 10.57 & $0.19 \pm 0.02$ & $0.95 \pm 0.20$ & $45.19 \pm 11.29^{a}$ \\
\hline
\end{tabular}

${ }^{\mathrm{a}-\mathrm{c}}$ Different letters in the same column indicate statistical significant differences at the level of $P<0.001$.

${ }^{1} \mathrm{~F} 1=\mathrm{cow}$ milk; F2 = cow milk after skimming and the first thermal treatment; F3 = concentrated milk after the second thermal treatment; F4 = concentrated infant formula after the last thermal treatment; F5 = the infant formula final product; and SW = milk whey used as an ingredient.

${ }^{2}$ Data of NPN and digestibility represent mean \pm SD. 
fragments may have preserved similar bioactivity of the origin sequence and must be taken in consideration for further studies.

The differences observed in the peptidic profile in each step of the processing could be related to the sequence and conditions of heat treatments along the manufacturing process. Because Maillard conjugation could modulate the functionality and digestibility of milk proteins, the knowledge of how processing under well-controlled conditions changes the peptides release after gastrointestinal digestion could be useful for improving functionality through the generation of bioactive peptides (Corzo-Martínez et al., 2012; Joubran et al., 2015).

Antimicrobial and immunomodulatory peptides, together with polyamines, may be responsible for the different susceptibility to some diseases between formula-fed and breast-fed infants. Angiotensin Iconverting enzyme-inhibitory peptides may play a role in cardiovascular health (Wada and Lönnerdal, 2014), and antioxidant peptides may protect infants from oxidative stress-associated diseases, such as necrotizing enterocolitis (Okur et al., 1995).

\section{CONCLUSIONS}

The present study confirms that the infant formula manufacturing process determines, together with raw milk composition, the polyamine content and peptidic profile after digestion of the infant formula. Therefore, compositional dissimilarity between human milk and infant formula in polyamines and proteins, and the functionality of these proteins and their peptides, could be responsible for some of the differences in health reported between breast-fed and formula-fed children. These changes must be taken into consideration because they may have a great effect on infant nutrition and development. Further studies are important to address the effects of the manufacturing process in protein digestibility, peptides profile, and polyamine content during formulation of infant formulas for the potential implication in human health.

\section{ACKNOWLEDGMENTS}

This work was supported by Consolider Fun-C-Food CSD2007-00063 from the Spanish Ministry of Science and Innovation. C. Gómez-Gallego was a recipient of the Seneca predoctoral grant (05001/FPI/06) from the Seneca Foundation (Regional Agency of Science and Technology of Murcia Region, Spain). The funders had no role in the design, analysis, or writing of this article.

\section{REFERENCES}

AOAC. 1990. Official Methods of Analysis. 15th ed. Assoc. Off. Anal. Chem., Washington, DC.

Barbé, F., O. Ménard, Y. Le Gouar, C. Buffière, M. H. Famelart, B. Laroche, S. Le Feunteun, D. Dupont, and D. Rémond. 2013. The heat treatment and the gelation are strong determinants of the kinetics of milk proteins digestion and of the peripheral availability of amino acids. Food Chem. 136:1203-1212.

Binaghi, M. J., A. Baroni, C. Greco, P. A. Ronayne de Ferrer, and M. Valencia. 2002. Estimación de proteína potencialmente utilizable en fórmulas infantiles de inicio para neonatos prematuros y de término. Archivos Latinoamericanos de Nutrición 52:43-47.

Blaschuk, O. W., B. J. Gour, S. Byers, and J. M. Symonds. 1999. Compounds and methods for modulating nonclassical cadherinmediated functions. US Pat. No. EP 1970383 A1.

Bosscher, D., Z. Lu, G. Janssens, M. Van Caillie-Bertrand, H. Robberecht, H. De Rycke, R. De Wilde, and H. Deelstra. 2001. In vitro availability of zinc from infant foods with increasing phytic acid contents. Br. J. Nutr. 86:241-247.

Bourlieu, C., O. Ménard, K. Bouzerzour, G. Mandalari, A. Macierzanka, A. R. Mackie, and D. Dupont. 2014. Specificity of infant digestive conditions: Some clues for developing relevant in vitro models. Crit. Rev. Food Sci. Nutr. 54:1427-1457.

Buts, J. P., N. De Keyser, L. De Raedemaeker, E. Collette, and E. M. Sokal. 1995. Polyamine profiles in human milk, infant artificial formulas, and semi-elemental diets. J. Pediatr. Gastroenterol. Nutr. 21:44-49.

Chang, K. J., A. Lillian, E. Hazum, P. Cuatrecasas, and J. K. Chang. 1981. Morphiceptin (NH4-tyr-pro-phe-pro-COHN2): A potent and specific agonist for morphine (mu) receptors. Science 212:75-77.

Clare, D. A., and H. E. Swaisgood. 2000. Bioactive milk peptides: A prospectus. J. Dairy Sci. 83:1187-1195.

Contreras, M. M., R. Carrrón, M. J. Montero, M. Ramos, and I. Recio. 2009. Novel casein-derived peptides with antihypertensive activity. Int. Dairy J. 19:566-573.

Corzo-Martínez, M., C. Carrera Sánchez, F. J. Moreno, J. M. Rodríguez Patino, and M. Villamiel. 2012. Interfacial and foaming properties of bovine b-lactoglobulin: Galactose Maillard conjugates. Food Hydrocoll. 27:438-447.

Dorhout, B., C. M. Van Beusekom, M. Huisman, A. W. Kingma, E. De Hoog, E. R. Boersma, and F. A. Muskiet. 1996. Estimation of 24-hour polyamine intake from mature human milk. J. Pediatr. Gastroenterol. Nutr. 23:298-302.

Escribano, M. I. 1990. Aspectos del metabolismo y transporte de poliaminas en Evernia prunastri (L.) ACH. PhD Thesis. Univ. Complutense Madrid, Madrid, Spain.

Frontela, C., J. F. Haro, G. Ros, and C. Martínez. 2008. Effect of dephytinization and follow-on formula addition on in vitro iron, calcium and zinc availability from infant cereals. J. Agric. Food Chem. 56:3805-3811.

Gómez-Gallego, C., M. C. Collado, G. Pérez, T. Ilo, U. M. Jaakkola, M. J. Bernal, M. J. Periago, R. Frias, G. Ros, and S. Salminen. 2014a. Resembling breast milk: Influence of polyamine-supplemented formula on neonatal BALB/cOlaHsd mouse microbiota. Br. J. Nutr. 111:1050-1058.

Gómez-Gallego, C., R. Frias, G. Pérez-Martínez, M. J. Bernal, M. J. Periago, S. Salminen, G. Ros, and M. C. Collado. 2014b. Polyamine supplementation in infant formula: Influence on lymphocyte populations and immune system-related gene expression in a Balb/cOlaHsd mouse model. Food Res. Int. 59:8-15.

Gueimonde, M., K. Laitinen, S. Salminen, and E. Isolauri. 2007. Breast milk: A source of bifidobacteria for infant gut development and maturation? Neonatology 92:64-66.

Gupta, A., B. Mann, R. Kumar, and B. S. Ram. 2010. Identification of antioxidant peptides in cheddar cheese made with adjunct culture Lactobacillus casei ssp. casei 300. Milchwissenschaft 5:396-399.

Hernández-Ledesma, B., L. Amigo, M. Ramos, and I. Recio. 2004. Application of high-performance liquid chromatography-tandem mass spectrometry to the identification of biologically active peptides 
produced by milk fermentation and simulated gastrointestinal digestion. J. Chromatogr. A 1049:107-114.

Hernández-Ledesma, B., A. Quirós, L. Amigo, and I. Recio. 2007. Identification of bioactive peptides after digestion of human milk and infant formula with pepsin and pancreatin. Int. Dairy J. 17:42-49.

Jiménez-Saiz, R., J. Belloque, E. Molina, and R. Lopez-Fandiño. 2011. Human immunoglobulin E ( $\mathrm{IgE}$ ) binding to heated and glycated ovalbumin and ovomucoid before and after in vitro digestion. J. Agric. Food Chem. 59:10044-10051.

Joubran, Y., A. Moscovici, and U. Lesmes. 2015. Antioxidant activity of bovine alpha lactalbumin Maillard products and evaluation of their in vitro gastro-duodenal digestive proteolysis. Food Funct. 6:1229-1240.

Jovani, M., R. Barberá, R. Farré, and E. Martín de Aguilera. 2001. Calcium, iron and zinc uptake from digest of infant formulas by Caco-2 cells. J. Agric. Food Chem. 49:3480-3485.

Kohmura, M., N. Nio, and Y. Ariyoshi. 1990. Inhibition of angiotensin-converting enzyme by synthetic peptide fragments of human k-casein. Agric. Biol. Chem. 54:835-836.

Korhonen, H., and A. Pihlanto-Leppäla. 2007. Technological options for the production of health-promoting proteins derived from milk and colostrum. Curr. Pharm. Des. 13:829-843.

Korhonen, H., A. Pihlanto-Leppäla, P. Rantamäki, and T. Tupasela. 1998. Impact of processing on bioactive proteins and peptides. Trends Food Sci. Technol. 9:307-319.

Larqué, E., M. Sabater-Molina, and S. Zamora. 2007. Biological significance of dietary polyamines. Nutrition 23:87-95.

Lee, H. S., and K. J. Lee. 2000. Cathepsin B inhibitory peptides derived from beta-casein. Peptides 21:807-809.

Maruyama, S., H. Mitachi, H. Tanaka, N. Tomizuka, and H. Suzuki. 1987. Angiotensin-I converting enzyme inhibitory activity of the C-terminal hexapeptide of a-casein. Agric. Biol. Chem. 51:25572561.

Matsufuji, H., T. Matsui, E. Seki, K. Osajima, M. Nakashima, and Y. Osajima. 1994. Angiotensin-I-converting enzyme inhibitory peptides in alkaline protease hydrolyzate derived from sardine muscle. Biosci. Biotechnol. Biochem. 58:2244-2245.

Michalski, M. C., and C. Januel. 2006. Does homogenization affect the human health properties of cow's milk? Trends Food Sci. Technol. 17:423-437.

Miller, D. D., B. R. Schrinker, R. R. Rasmussen, and D. Van Campen. 1981. An in vitro method for estimation of iron availability from meal. Am. J. Clin. Nutr. 34:2248-2256.

Mullally, M. M., H. Meisel, and R. J. FitzGerald. 1996. Synthetic peptides corresponding to alpha-lactalbumin and beta-lactoglobulin sequences with angiotensin-I-converting enzyme inhibitory activity. Biol. Chem. Hoppe-Seyler. 377:259-260.

Nagaoka, S., Y. Futamura, K. Miwa, T. Awano, K. Yamauchi, Y. Kanamaru, K. Tadashi, and T. Kuwata. 2001. Identification of novel hypocholesterolemic peptides derived from bovine milk $\beta$-lactoglobulin. Biochem. Biophys. Res. Commun. 281:11-17.

Newburg, D. S., and W. A. Walker. 2007. Protection of the neonate by the innate immune system of developing gut and of human milk. Pediatr. Res. 61:2-8.

Nishibori, N., S. Fujihara, and T. Akatuki. 2007. Amounts of polyamines in foods in Japan and intake by Japanese. Food Chem. 100:491-497.

Okur, H., M. Kükükaydin, K. Köse, O. Kontas, P. Dogam, and A. Kazez. 1995. Hypoxia-induced necrotizing enterocolitis in the immature rat, the role of lipid peroxidation and management by vitamin E. J. Pediatr. Surg. 30:1416-1419.

Pellegrini, A., C. Dettilng, U. Thomas, and P. Hunziker. 2001. Isolation and characterization of four bactericidal domains in the bovine beta-lactoglobulin. Biochim. Biophys. Acta 1526:131-140.

Pérez-Cano, F. J. A. González-Castro, C. Castellote, A. Franch, and M. Castell. 2010. Influence of breast milk polyamines on suckling rat immune system maturation. Dev. Comp. Immunol. 34:210-218.

Pollack, P. F., O. Koldousky, and F. Nishioka. 1992. Polyamines in human and rat milk and in infant formulas. Am. J. Clin. Nutr. $56: 371-375$.

Romain, N., G. Dandrifosse, F. Jeusette, and P. Forget. 1992. Polyamine concentration in rat milk and food, human-milk, and infant formulas. Pediatr. Res. 32:58-63.

Rudloff, S., and B. Lönnerdal. 1992. Solubility and digestibility of milk proteins in infant formulas exposed to different heat treatments. J. Pediatr. Gastroenterol. Nutr. 15:25-33.

Shahidi, F., and Y. Zhong. 2008. Bioactive peptides. J. AOAC Int 91:914-931.

Suzuki, O., T. Matsumoto, and Y. Katsumata. 1984. Determination of polyamine oxidase activities in human tissues. Experientia 40:838-839.

Tovar, D. 2002. Potencial probiótico de levaduras productoras de poliaminas en el desarrollo del sistema digestivo de la lubina Europea Dicentrarchus labrax y la cabrilla arenera Paralabrax maculatofasciatus. PhD Thesis. Centro de Investigaciones Biológicas del Noroeste, SC, México.

Wada, Y., and B. Lönnerdal. 2014. Bioactive peptides derived from human milk proteins-Mechanisms of action. J. Nutr. Biochem. 25:503-514. 